\title{
RESEARCH PAPER \\ IONIZING RADIATION MEASUREMENTS AND ASSAY OF CORRESPONDING DOSE RATE AROUND BOTTLING AND PHARMACEUTICAL FACILITIES IN ILORIN, NIGERIA
}

\author{
L. I. Nwankwo*, D. F. Adeoti, and A. J. Folarin \\ Department of Physics, University of Ilorin, Ilorin 240003, Nigeria \\ *Corresponding Author: levinwankwo@yahoo.com; linwankwo@unilorin.edu.ng
}

\begin{abstract}
Measurements of ionizing radiation and corresponding dose rate around bottling and pharmaceutical facilities in Ilorin, Nigeria, have been carried out using three duly calibrated Radalert Nuclear Radiation Meters and Global Positioning System. The survey meters were held at $1 \mathrm{~m}$ above the ground surface while obtaining readings at 31 locations within the study area. Measured radiation levels range from $1.14 \pm 0.09$ to $2.48 \pm 0.13 \mathrm{mSv} / \mathrm{yr}$ with a mean of $1.60 \pm 0.26 \mathrm{mSv} /$ $y r$. The result shows that the exposure rates for all the stations are higher than the radiation dose limit of $1 \mathrm{mSv} / \mathrm{yr}$ for individual members of the public, while three stations are above the global average of $2.4 \mathrm{mSv} / \mathrm{yr}$. It is recommended that areas with readings above global average be monitored closely to protect the public from adverse health effects.
\end{abstract}

Keywords: Gamma radiation, Ionizing, Dose Rate, Ilorin, Nigeria

\section{INTRODUCTION}

Industrial activities account for a significant percentage of contribution to total environmental pollution and general degradation of the natural environment that we experience today (Oke 2004; Inyang et al., 2009; EEA, 2011). Our environment contains naturally occurring radioactive materials, which spontaneously disintegrate to form stable nuclei and in the process release radiation to the environment (IAEA, 2004). In addition, technologically enhanced naturally occurring radioactive materials are produced as a result of industrial activi- ties, which also contribute to the average radiation profile of the environment (NNRA, 2006). Hence the background ionizing radiation of the environment is a combination of natural and man-made sources (Chukwuocha and Enyinna, 2010). It is established that high level of radiation, above tolerable limits, carries serious health implications. Therefore, it is important that the quality of our environment be maintained in a good state, to ensure a high level of social performance that can be achieved by close monitoring of pollution factors (Avwiri et al., 2009). 


\section{$85 \quad$ Nwankwo et al.}

Radiation monitoring is a continuous or periodic measurement of dose or contamination for reasons related to the assessment or control of exposure to radiation or radioactive substances (IAEA, 2007). This is aimed at preventing deterministic health effects and reducing stochastic effects of radiation to an acceptable level (ICRP, 2012; 2013; UNSCEAR, 2001; USNRC, 2005). According to international recommendations, occupational exposure to radiation should not exceed $20 \mathrm{mSv} / \mathrm{yr}$, while the public should not be exposed to more than an average of $1 \mathrm{mSv} / \mathrm{yr}$ (IAEA, 2004; Strom, 2003; USNRC, 2005; UNSCEAR, 2008), as depicted in Table 1.

Previous radiation study carried out at AsaDam industrial area of Ilorin, Nigeria showed that the average radiation level was approximately $1.13 \mathrm{mSv} / \mathrm{yr}$ (Nwankwo and Akoshile, 2005). In a similar work done by Chukwuocha and Enyinna (2010) within petroleum drilling areas of Rivers State, the authors showed that the average exposure rates ranged between 1.14 $-1.18,1.09-1.18,1.09-1.16$ and $1.18-1.22$ $\mathrm{mSv} / \mathrm{yr}$ for the turbine joints, rig equipment environment, wellheads and mud tanks respectively.

Likewise, Chad-Umoren and Briggs-Kamara (2010), surveyed the distribution of environmental ionizing radiation in Rivers State. The results show a mean dose equivalent of $0.745 \pm 0.085 \mathrm{mSv} / \mathrm{yr}$ (for upland campus environment), $0.690 \pm 0.170 \mathrm{mSv} / \mathrm{yr}$ (for rural riverine communities) and $1.270 \pm 0.087 \mathrm{mSv} / \mathrm{yr}$ (for industrial zone), which indicate an inhomogeneous radiation profile within the state. They concluded that the differences may be due to variations in levels of industrial activities in the area. Similar increase in environmental radioactivity in other cities in Nigeria has also been reported (Ajayi, 2001; Kuforiji et al., 2003; Arogunjo et al., 2004; Isinkaye and Ajayi 2006; Ajayi et al., 2006; Ademola, 2008; Farai et al., 2008; Farai and Ademola, 2005; Alatise et al., 2008; Inyang et al., 2009).
This study involves the determination of ionizing radiation levels around bottling and pharmaceutical facilities in Ilorin metropolis with a view to assessing whether the radiation profile is within tolerable limit.

\section{The Study Area}

The study area falls within the central part of Ilorin, Nigeria (Fig.1). This area lies entirely within the basement complex terrain of Nigeria. The basement rocks are mainly bounded gneiss and auger gneiss with granodiorites and granites intrusions. The Nigeria basement complex consists of at least four main groups of rocks: The migmatite gneiss complex, the metasediment (composed of schist, calc-gneiss, quartizite and meta-conglomerate), the porphyritic older granite and the miscellaneous rock types, which are mostly post orogenic rocks like aplite, pegmatites, and dolerites dykes. These rocks are younger and are found to cut through pre-existing rocks (Rahaman, 1973).

\section{METHOD OF STUDY}

\section{Basic Theoretical Considerations}

The fundamental equation of radioactivity is based on the concept of radioactivity decay. This decay is a phenomenon by which large number of nuclei spontaneously emits elementary particles or nuclear radiation. The rate of decay has been found to be proportional to the number of nuclei $\mathrm{N}$ present in the material (Weinert, 2009; Kragh, 2012):

$-\frac{d N}{d t} \propto N$

where the negative sign indicates increasing $\mathrm{N}$ as time $t$ increases.

Consequently, the radioactive decay law is derived:

$\frac{d N}{d t}=-\lambda N$

where $\lambda$ is a positive constant called decay con- 
Ionizing radiation measurements and assay of corresponding dose rate... 86

Table 1: Basic exposure limits

\begin{tabular}{|c|c|c|}
\hline Exposure & $\begin{array}{l}\text { IAEA Basic Safety Standards } \\
\text { (Safety Series-15) }\end{array}$ & ICRP-103 \\
\hline $\begin{array}{l}\text { Effective Dose Annual } \\
\text { (Occupational) } \\
\text { Effective Dose Cumulative } \\
\text { (Occupational) }\end{array}$ & $\begin{array}{l}20 \mathrm{mSv} / \mathrm{y} \text { averaged } 5 \text { years, not } \\
\text { exceed } 50 \mathrm{mSv} \text { in any single year }\end{array}$ & $\begin{array}{l}20 \mathrm{mSv} / \mathrm{y} \text { averaged } 5 \text { years, not exceed } \\
50 \mathrm{mSv} \text { in any single year }\end{array}$ \\
\hline $\begin{array}{l}\text { Equivalent Dose Annual } \\
\text { (Occupational) }\end{array}$ & $\begin{array}{l}\text { For lens of eye: } 20 \mathrm{mSv} / \mathrm{y} ; 500 \\
\mathrm{mSv} / \mathrm{y} \text { for skin, hands and feet }\end{array}$ & $\begin{array}{l}\text { For lens of eye, Skin and hands and feet: } \\
20 \mathrm{mSv} / \mathrm{y} \text { averaged } 5 \text { years, not exceed } \\
50 \mathrm{mSv} \text { in any single year }\end{array}$ \\
\hline $\begin{array}{l}\text { Effective Dose Annual } \\
\text { (Public) }\end{array}$ & $1 \mathrm{mSv} / \mathrm{y}$ & $\begin{array}{l}1 \mathrm{mSv} / \mathrm{y} \text {; higher if needed, provided 5- } \\
\mathrm{yr} \text { annual average is less or equal to } 1 \\
\mathrm{mSv}\end{array}$ \\
\hline $\begin{array}{l}\text { Equivalent Dose Annual } \\
\text { (Public) }\end{array}$ & $\begin{array}{l}15 \mathrm{mSv} / \mathrm{y} \text { for lens of eye; } 50 \mathrm{mSv} / \mathrm{y} \\
\text { for skin, hands, feet }\end{array}$ & $\begin{array}{l}15 \mathrm{mSv} \text { lens of eye; } 50 \mathrm{mSv} \text { skin, hands, } \\
\text { feet }\end{array}$ \\
\hline
\end{tabular}

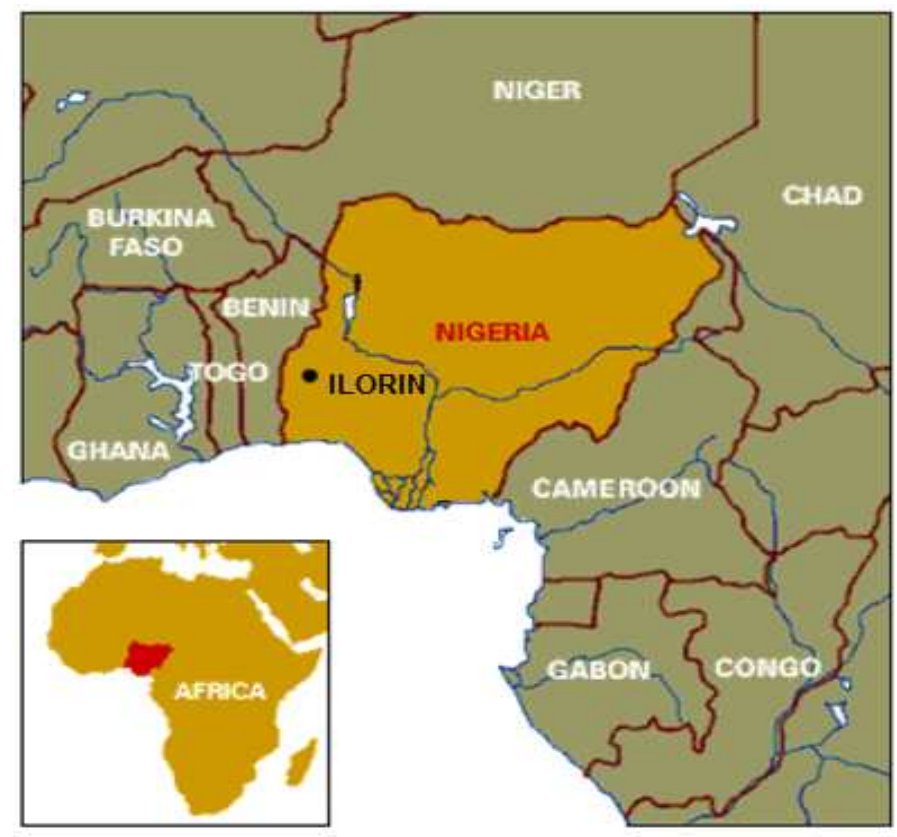

Fig. 1: Geographical map of Nigeria showing Ilorin City

stant. It depends on the radioactive material and has a unit of $s^{-1}$

The solution of Equation 2 has a form which gives what happens at all times:
$N_{t}=N_{0} \exp (-\lambda t)$

where $N_{0}$ is the amount of material at time $\mathrm{t}=0$.

Equation 3 shows that the number of radioac- 


\section{Nwankwo et al.}

tive nuclei will decrease exponentially with time and the rate of decrease being controlled by the decay constant $\lambda$. Invariably, when the decay constant has a low value, the exponential curve decreases relatively slowly and when high, the curve decreases very quickly.

Another important concept is the Half Life. This is the time taken for the radioactive material to decrease by half. This is shown mathematically as:

$N_{T}=\frac{N_{0}}{2}=N_{0} \exp (-\lambda T)$

and

$T=\frac{1}{\lambda} \ln 2$

Equation 5 gives the relationship between radioactive decay constant and half-life. The halflives of some materials and the radiation released by them are shown in Table 2 .

\section{Field Measurements}

In-situ measurements of the background radiation level were carried out using three portable Nuclear Radiation Monitors (Radalert-100) and Global Positioning System (GPS). Calibration of the monitors was done using Cesium-137 as the standard radionuclide. The procedure for calibration is as reported in the monitors' operating manual (International Medcom, 2006). Field measurements were taken simultaneously using the three monitors at every 20 minutes interval for 10 successive readings per station.

Following standard procedure, the window of the radiation meters was held at a height of 1.0 $\mathrm{m}$ above the ground level (Kurnaz et al., 2011). Thirty one (31) measurement points were strategically selected for adequate coverage of the industrial facilities in the study area.

Readings from the Radalert-100 monitors were obtained in units of $\mathrm{mR} / \mathrm{hr}$ but recorded in $\mathrm{mSv} /$ yr. The conversion was done as follows: one
(1) $\mathrm{mR} / \mathrm{hr}$ is approximately equal to $9.6 \times 10^{-3}$ $\mathrm{mSv} / \mathrm{hr}$; consequently, multiplying by the number of hours in a day (24) and the number of days in a year (365.242), the resulting conversion gives the results in $\mathrm{mSv} / \mathrm{yr}$.

\section{RESULTS AND DISCUSSION}

The results obtained from the measurements represent the external background radiation level of the studied area. The mean of the readings from each measurement location is shown in Tables 3 and 4.

The measured radiation levels for the studied locations range from $1.14 \pm 0.09$ to $1.86 \pm 0.15$ $\mathrm{mSv} / \mathrm{yr}$, with an average of $1.48 \pm 0.19 \mathrm{mSv} / \mathrm{yr}$ for Tuyil zone and $1.25 \pm 0.13$ to $2.48 \pm 0.13$ $\mathrm{mSv} / \mathrm{yr}$, with an average of $1.71 \pm 0.18 \mathrm{mSv} / \mathrm{yr}$ for bottling zone, while $1.14 \pm 0.09$ to $2.48 \pm 0.13$ $\mathrm{mSv} / \mathrm{yr}$, with an average of $1.60 \pm 0.26 \mathrm{mSv} / \mathrm{yr}$ is recorded for the entire surveyed area. The results reveal that the areas around the bottling facilities have the highest radiation levels ( $\geq 2$ $\mathrm{mSv} / \mathrm{yr}$ ), with three measurement points having readings above global average $(\geq 2.4 \mathrm{mSv} /$ yr) for the general public. It has been reported that each member of the world population is exposed, on average, to $2.4 \mathrm{mSv} / \mathrm{yr}$ of ionizing radiation from natural sources (WHO, 2012). The results also show that the exposure rates for all the locations are more than the radiation dose limit of $1 \mathrm{mSv} / \mathrm{yr}$ for individual members of the public (USNRC, 2005). Comparisons of the mean exposure rates of each surveyed zone and that of the entire area with the dose limit are shown in Figs 2 and 3 respectively. Laboratory analysis of some soil samples in the area using gamma-ray spectroscopy revealed the presence of naturally occurring radionuclides.

Average activities of 412.27, 11.24 and 12.01 $\mathrm{Bq} / \mathrm{kg}$ were obtained for ${ }^{40} \mathrm{~K},{ }^{238} \mathrm{U}$ and ${ }^{232} \mathrm{Th}$ respectively, which give an estimated dose equivalent value of $0.27 \mathrm{mSv} / \mathrm{yr}$. This is found to be within the typical range of $0.2-0.6 \mathrm{mSv} /$ $\mathrm{yr}$ for average terrestrial gamma rays exposure due to radionuclides in the soil (WHO, 2012). Therefore, it could be suggested that more con- 
Ionizing radiation measurements and assay of corresponding dose rate... 88

Table 2: Natural radiation decay series (Radiation, 2013)

\begin{tabular}{lll}
\hline Radioisotope & Half Life (approx.) & Radiation \\
\hline Uranium-238 & 4.47 billion years & alpha, x-rays \\
Thorium-234 & 24.1 days & beta, gamma, x-rays \\
Protactinium-234m & 1.17 minutes & beta, gamma \\
Uranium-234 & 245,000 years & alpha, x-rays \\
Radon-222 & 3.83 days & Alpha \\
Polonium-218 & 3.05 minutes & Alpha \\
Lead-214 & 26.8 minutes & beta $(700 \mathrm{keV})$, gamma, x-rays \\
Bismuth-214 & 19.7 minutes & beta $(0.5,3 \mathrm{MeV})$, gamma \\
Polonium-214 & 164 microseconds & Alpha \\
Lead-210 & 22.3 years & beta, gamma, x-rays \\
Polonium-210 & 138 days & Alpha \\
Thorium-232 & 14.1 billion years & alpha, x-rays \\
Radium-228 & 5.75 years & Beta \\
Thorium-228 & 1.91 years & alpha, gamma, $x$-rays \\
Radium-224 & 3.66 days & alpha, gamma \\
Radon-220 & 55.6 seconds & Alpha \\
Polonium-216 & 0.15 seconds & Alpha \\
Lead-212 & 10.64 hours & beta $(335 \mathrm{keV})$, gamma, x-rays \\
Bismuth-212 & 60.6 minutes & alpha, beta, gamma, x-rays \\
Polonium-212 & 0.305 microseconds & Alpha \\
Potassium-40 & 1.28 billion years & beta (1.3 MeV), gamma \\
\hline
\end{tabular}

Table 3: Radiation levels around Tuyil pharmaceutical facilities

\begin{tabular}{|c|c|c|}
\hline Stations & GPS & Mean Radiation Level (mSv/yr) \\
\hline 1 & $\mathrm{~N}^{\circ} 8^{\circ} 28.869^{\prime} \mathrm{E}^{2} 04^{\circ} 33.324^{\prime}$ & $1.14 \pm 0.11$ \\
\hline 2 & $\mathrm{~N}^{\circ} 8^{\circ} 28.809^{\prime} \mathrm{E}^{\circ} 04^{\circ} 33.316^{\prime}$ & $1.14 \pm 0.09$ \\
\hline 3 & $\mathrm{~N}^{\circ} 8^{\circ} 28.779^{\prime} \mathrm{E}^{2} 04^{\circ} 33.311^{\prime}$ & $1.37 \pm 0.15$ \\
\hline 4 & $\mathrm{~N}^{\circ} 8^{\circ} 28.707^{\prime} \mathrm{E}^{2} 04^{\circ} 33.296^{\prime}$ & $1.70 \pm 0.23$ \\
\hline 5 & $\mathrm{~N}^{\circ} 8^{\circ} 28.669^{\prime} \mathrm{E}^{2} 04^{\circ} 33.283^{\prime}$ & $1.34 \pm 0.27$ \\
\hline 6 & $\mathrm{~N}^{\circ} 8^{\circ} 26.645^{\prime} \mathrm{E}^{2} 04^{\circ} 33.282^{\prime}$ & $1.49 \pm 0.27$ \\
\hline 7 & $\mathrm{~N}^{\circ} 8^{\circ} 28.610^{\prime} \mathrm{E}^{2} 04^{\circ} 33.270^{\prime}$ & $1.16 \pm 0.20$ \\
\hline 8 & $\mathrm{~N}^{\circ} 8^{\circ} 28.574^{\prime} \mathrm{E}^{2} 04^{\mathrm{o}} 33.268^{\prime}$ & $1.64 \pm 0.46$ \\
\hline 9 & $\mathrm{~N}^{\circ} 8^{\circ} 28.501^{\prime} \mathrm{E}^{2} 04^{\mathrm{o}} 33.243^{\prime}$ & $1.78 \pm 0.13$ \\
\hline 10 & $\mathrm{~N}^{\circ} 8^{\circ} 28.468^{\prime} \mathrm{E}^{\circ} 04^{\mathrm{o}} 33.236^{\prime}$ & $1.82 \pm 0.16$ \\
\hline 11 & $\mathrm{~N}^{\circ} 8^{\circ} 28.458^{\prime} \mathrm{E}^{2} 04^{\circ} 33.174^{\prime}$ & $1.86 \pm 0.15$ \\
\hline 12 & $\mathrm{~N}^{\circ} 8^{\circ} 28.453^{\prime} \mathrm{E}^{2} 04^{\circ} 32.202^{\prime}$ & $1.62 \pm 0.08$ \\
\hline 13 & $\mathrm{~N}^{\circ} 8^{\circ} 28.411^{\prime} \mathrm{E}^{2} 04^{\circ} 33.231^{\prime}$ & $1.47 \pm 0.19$ \\
\hline \multirow[t]{2}{*}{14} & $\mathrm{~N}^{2} 8^{\circ} 752^{\prime} \mathrm{E}^{\circ} 04^{\circ} 33.295^{\prime}$ & $1.25 \pm 0.16$ \\
\hline & Average & $1.48 \pm 0.19$ \\
\hline
\end{tabular}


89 Nwankwo et al.

Table 4: Radiation levels around bottling facilities

\begin{tabular}{|c|c|c|}
\hline Stations & GPS & Mean Radiation Level (mSv/yr) \\
\hline 1 & $\mathrm{~N}^{\prime} 8^{\circ} 27.995^{\prime} \mathrm{E}^{\circ} 04^{\circ} 33.633^{\prime}$ & $1.51 \pm 0.06$ \\
\hline 2 & $\mathrm{~N}^{\circ} 8^{\circ} 28.037^{\prime} \mathrm{E}^{\circ} 04^{\circ} 33.624^{\prime}$ & $1.74 \pm 0.08$ \\
\hline 3 & $\mathrm{~N}^{\circ} 8^{\circ} 28.067^{\prime} \mathrm{E}^{\circ} 04^{\circ} 33.62^{\prime}$ & $1.51 \pm 0.23$ \\
\hline 4 & $\mathrm{~N}^{\circ} 8^{\circ} 28.083^{\prime} \mathrm{E}^{\circ} 04^{\circ} 33.62^{\prime}$ & $1.69 \pm 0.17$ \\
\hline 5 & $\mathrm{~N}^{\prime} 8^{\circ} 28.134^{\prime} \mathrm{E} 004^{\circ} 33.624^{\prime}$ & $1.67 \pm 0.11$ \\
\hline 6 & $\mathrm{~N}^{\circ} 8^{\circ} 28.183^{\prime} \mathrm{E}^{\circ} 04^{\circ} 33.629^{\prime}$ & $2.40 \pm 0.33$ \\
\hline 7 & $\mathrm{~N}^{\prime} 8^{\circ} 28.221^{\prime} \mathrm{E}^{\circ} 04^{\circ} 33.633^{\prime}$ & $2.48 \pm 0.13$ \\
\hline 8 & $\mathrm{~N}^{\circ} 8^{\circ} 28.273^{\prime} \mathrm{E} 004^{\circ} 33.639^{\prime}$ & $1.25 \pm 0.13$ \\
\hline 9 & $\mathrm{~N}^{\circ} 8^{\circ} 28.504^{\prime} \mathrm{E} 004^{\circ} 33.652^{\prime}$ & $1.96 \pm 0.19$ \\
\hline 10 & $\mathrm{~N}^{\prime} 8^{\circ} 28.327^{\prime} \mathrm{E} 004^{\circ} 33.662^{\prime}$ & $2.41 \pm 0.27$ \\
\hline 11 & $\mathrm{~N}^{2} 8^{\circ} 28.376^{\prime} \mathrm{E}^{\circ} 04^{\circ} 33.654^{\prime}$ & $1.30 \pm 0.13$ \\
\hline 12 & $\mathrm{~N}^{\prime} 8^{\circ} 28.420^{\prime} \mathrm{E}^{\circ} 04^{\circ} 33.669^{\prime}$ & $1.48 \pm 0.09$ \\
\hline 13 & $\mathrm{~N}^{\prime} 8^{\circ} 28.480^{\prime} \mathrm{E}^{\circ} 04^{\circ} 33.670^{\prime}$ & $1.57 \pm 0.16$ \\
\hline 14 & $\mathrm{~N}^{\circ} 8^{\circ} 28.491^{\prime} \mathrm{E} 004^{\circ} 33.650^{\prime}$ & $1.64 \pm 0.20$ \\
\hline 15 & 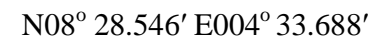 & $1.59 \pm 0.19$ \\
\hline 16 & $\mathrm{~N}^{2} 8^{\circ} 28.608^{\prime} \mathrm{E}^{\circ} 04^{\circ} 33.692^{\prime}$ & $1.51 \pm 0.33$ \\
\hline \multirow[t]{2}{*}{17} & $\mathrm{~N}^{\circ} 8^{\circ} 28.327^{\prime} \mathrm{E} 004^{\circ} 33.662^{\prime}$ & $1.41 \pm 0.23$ \\
\hline & Average & $1.71 \pm 0.18$ \\
\hline
\end{tabular}

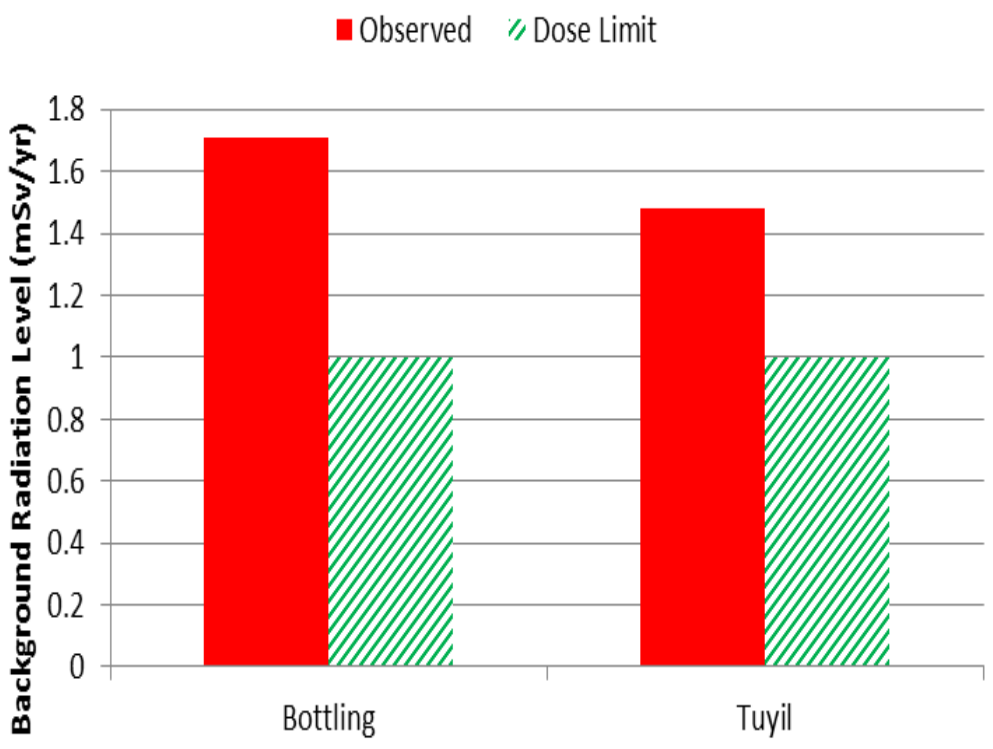

Fig. 2: Mean background radiation profile of each surveyed zone compared with radiation dose limit of $1 \mathrm{mSv} / \mathrm{yr}$ (USNRC, 2005) for the public. 
Ionizing radiation measurements and assay of corresponding dose rate... 90

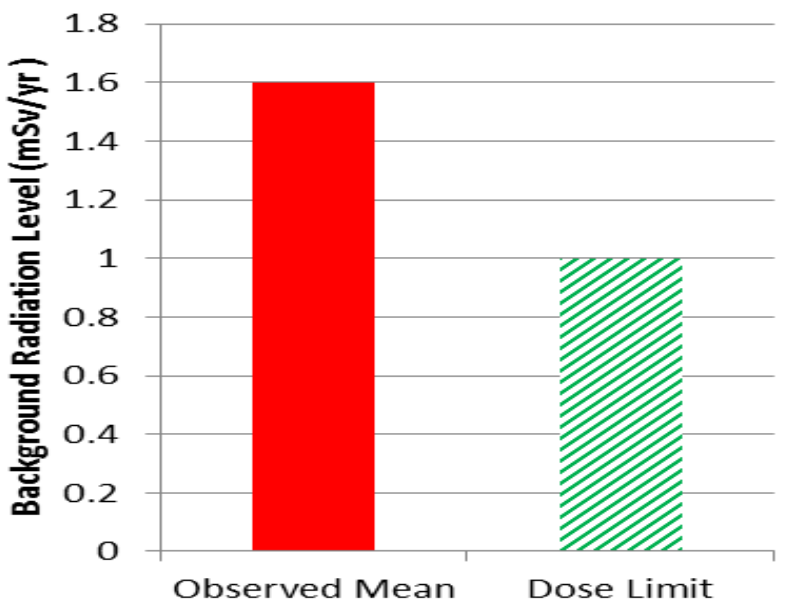

Fig. 3: Mean background radiation profile of the entire surveyed area compared with radiation dose limit of $1 \mathrm{mSv} / \mathrm{yr}$ (USNRC, 2005) for the public

tributions to the radiation profile of the area are from other sources.

\section{CONCLUSION}

This study reveals the levels of external background radiation in parts of Ilorin where very little published data exists on such topics. Although the radiation levels measured in the study area are far below the safe radiation limit as recommended for non-nuclear work environment, the levels recorded are higher than the standard background radiation level for the general public. More so, three of the surveyed stations are above the global average for the general public. Although, the results obtained in this study may not pose any serious health implication to the occupational worker, it is highly recommend that the areas with considerable high readings $(\geq 2.4 \mathrm{mSv} / \mathrm{yr})$ be monitored closely to protect the general public from adverse health effects and remedial solution should be taken.

\section{REFERENCES}

Ademola, J. A. (2008). Determination of natural radionuclides content in some building materials in Nigeria by gamma-ray spectrometry. Health Physics, 94: $43-8$.

Ajayi, I. R. (2001). Radionuclides measurement and assay of soil and their corresponding absorbed dose rate in air in Aramoko-Ekiti, Nigeria. Journal of Radioanalytical and $\mathrm{Nu}$ clear Chemistry, 250: 571-572.

Ajayi, I. R., Adegbuyi, O., Afolabi, O. M. and Oniya, E. O. (2006). Terrestrial gamma dose rates in Akoko, Southwestern Nigeria. Science Research Annals, 2: 53 - 57.

Alatise, O. O., Babalola, I. A. and Olowofela, J. A. 2008. Distribution of some natural gamma emitting radionuclides in the soils of coastal areas of Nigeria. Journal of Environmental Radioactivity, 99: 1746 - 1749.

Arogunjo, A. M., Farai, I. P. and Fowape, A. (2004). Dose rate assessment of terrestrial gamma radiation in the delta region of Nigeria. Radiation Protection Dosimetry, 108: 73 77. 


\section{Nwankwo et al.}

Avwiri, G. O., Chad-Umoren, Y. E., Enyinna, P. I. and Agbalagba, E. O. (2009). Occupational radiation profile of oil and gas facilities during production and off- production periods in Ughelli, Nigeria. FACTA UNIVERSITATIS: Working and Living Environmental Protection 6: $11-19$.

Chad-Umoren, Y. E. and Briggs-Kamara, M. A. (2010). Environmental ionizing radiation distribution in Rivers State, Nigeria. Journal of Environmental Engineering and Landscape Management, 18(2): 154-161.

Chukwuocha, E. O. and Enyinna, P. I. (2010). Radiation Monitoring of Facilities in some Oil wells in Bayelsa and Rivers States. Scientia Africana, 9: 98 - 102.

European Environment Agency. (2011). Revealing the costs of air pollution from industrial facilities in Europe. EEA Technical Report No. 15, Denmark.

Farai, I. P. and Ademola, J. A. (2005). Radium equivalent activity concentrations in concrete building blocks in eight cities in Southwestern Nigeria. Journal of Environmental Radioactivity, 79: $119-25$.

Farai, I. P., Okwunakwe, C. S. and Makinde, O. S. (2008). Gamma spectroscopic assay of soil samples from waste dump sites in Port Harcourt, Nigeria. Applied Radiation and Isotopes, 66 (6-7): 850-854.

International Commission on Radiological Protection. (ICRP)(2012). Compendium of Dose Co-efficients based on ICRP Publication 60. ICRP Publication 119. Ann. ICRP 41.

International Commission on Radiological Protection. (2013). Publication 121: Radiological Protection in Paediatric Diagnostic and Interventional Radiology, Annals of the ICRP, 42 (2): 1 - 63.

International Atomic Energy Agency. (IAEA)
(2004). Radiation, People and the Environment Report No. IAEA/PI/A.75/04-00391, Austria.

IAEA. (2007). Safety Glossary: Terminology Used in Nuclear Safety and Radiation Protection. STI/PUB/1290, Austria.

Isinkaye, M. O. and Ajayi, I. R. (2006). Background dose and radium equivalent measurement at Ikogosi - Ekiti, Nigeria. Radiation Protection Dosimetry, 121 (4): 466-468.

Inyang, S. O., Inyang, I. S. and Egbe, N. O. (2009). Radiation exposure levels within timber industries in Calabar, Nigeria. Journal of Medical Physics, 34 (2): 97-100.

International Medcom, 2006. Radalert $100 \mathrm{Nu}$ clear Radiation Monitor Operating Manual. h t t p : / / med com.com/downloads / Radalert100_manual.pdf Accessed on 24/4/2012

Kragh, H. (2012). Rutherford, Radioactivity, and the Atomic Nucleus. Paper given to meeting in Residencia Estudiantes, MadriD. Downloaded online at http://arxiv.org/ftp/ arxiv/papers/1202/1202.0954.pdf Accessed on $13 / 12 / 2012$

Kuforiji, O. O., Babalola, I. A. and Ajayi, I. R. (2003). Assessment of the Natural radioactivity in the coastal area of Lagos, Nigeria. Botswana Journal of Technology, 12 (1): 5357.

Kurnaz, A., Kucukomeroglu, B., Damla, N. and Cevik, U. (2011). Radiological maps for Trabzon, Turkey. Journal of Environmental Radioactivity, 102: 393-399.

Nigerian Nuclear Regulatory Authority. (2006). Report on Radiation safety regulations: Radiotherapy, Nuclear medicine and Diagnostic radiology, Lagos. 
Ionizing radiation measurements and assay of corresponding dose rate... 92

Nwankwo, L. I. and Akoshile, C. O. (2005). Monitoring of external background radiation level in Asa Dam industrial area of Ilorin, Kwara State, Nigeria. Journal of Applied Sciences and Environmental Management, 9 (3): $75-78$.

Oke, S. A. (2004). On the environmental pollution problem: A review, Journal of Environmental Engineering and Landscape Management, 12(3): 108-113.

Rahaman, M. A. (1973). Review of the basement Geology of South Western Nigeria. In C. A. Kobe (Ed) Geology of Nigeria. Rockview Publishers, Jos. $39-56$.

Strom, D. J. (2003). Health Impacts from Acute Radiation Exposure. U.S. Department of Energy. DE-AC06-76RLO 1830.

United Nations Scientific Committee on the Effects of Atomic Radiation. (UNSCEAR). (2001). Hereditary effects of radiation.
Report to the General Assembly, United Nations, Vienna.

United Nations Scientific Committee on the Effects of Atomic Radiation. (2008). Sources and effects of ionizing radiation. Report to the General Assembly with Scientific Annexes. Vol. 1. New York.

United States Nuclear Regulatory Commission. (2005). Nuclear Regulatory Commission Regulations, 10 CFR.

Weinert, F. (2009). Radioactive Decay Law (Rutherford-Soddy), in Compendium of Quantum Physics: Concepts, Experiments, History and Philosophy, D. Greenberger et al. (Eds). Springer-Verlag, Berlin Heidelberg. $630-632$

World Health Organization. (WHO) (2012). Guidelines for drinking-water quality: Radiological Aspects. Geneva. 